Agr. Biol. Chem., 38 (6), $1221 \sim 1225,1974$

\title{
Induction of Catalase Activity by Hydrocarbons in Candida tropicalis $\mathrm{pK} 233^{+}$
}

\author{
Yutaka Teranishi, Susumu Kawamoto, Atsuo Tanaka, \\ Masako Osumi* and Saburo FukuI*** \\ Laboratory of Industrial Biochemistry, Department of Industrial Chemistry, Faculty \\ of Engineering, Kyoto University, Kyoto, *Department of Biology, Japan \\ Women's University, Tokyo \\ Received February 5, 1974
}

1. The catalase activity of Candida tropicalis $\mathrm{pK} 233$ was induced by hydrocarbons but not by glucose, galactose, ethanol, acetate or lauryl alcohol.

2. The induction of the catalase activity depending upon hydrocarbons was sensitive to cycloheximide but not to chloramphenicol.

3. Glucose repressed strongly the induction of the catalase activity by hydrocarbons but galactose did not affect seriously.

4. When $C$. tropicalis was incubated with hydrocarbons, the appearance of microbodies was observed electronmicroscopically.

In the previous report, ${ }^{1}$ we described that several strains of hydrocarbon-grown Candida yeasts, especially Candida tropicalis, exhibited a high catalase activity and that profuse appearance of microbodies in the yeast cells was observed electronmicroscopically. These facts suggested that there would be a certain relationship among the catalase activity, the appearance of microbodies and the assimilation of hydrocarbons. However, the information of the physiological role of microbodies and also of catalase in the yeasts is very little. ${ }^{2,3)}$ Thus, this paper deals with the inducibility of the catalase activity by hydrocarbons and with concomitant increase of microbodies in $C$. tropicalis $\mathrm{pK} 233$.

\section{MATERIALS AND METHODS}

Cultivation of the yeast. The yeast used in this study, Candida tropicalis $\mathrm{pK} 233$, was kindly supplied by the National Fermentation Research Institute, Chiba, Japan. The organism was cultured in the same manner as that described in the previous paper.4

$\uparrow$ Studies on the Physiology and Metabolism of Hydrocarbon-utilizing Microorganisms. Part VII. This work was partly supported by the grant from the Ministry of Education, Japanese Government.

** To whom correspondence should be addressed.
Hydrocarbons used was "hydrocarbon mixture 6" (a mixture of $n-\mathrm{C}_{10} \sim \mathrm{C}_{13}$ )."

Preparation of the adapted cells. The yeast cells precultured on malt extract for $22 \mathrm{hr}$ were transferred to a hydrocarbon medium containing $1 \mathrm{v} / \mathrm{v} \%$ of $n$ alkane mixture $\left(\mathrm{C}_{10} \sim \mathrm{C}_{13}\right)$ as a sole carbon source, and cultured for $4 \mathrm{hr}$ at $30^{\circ} \mathrm{C}$ on a rotary shaker $(220 \mathrm{rpm})$. The partially induced cells thus obtained were transferred to the various media and cultivated for appropriate hours as indicated in the results. The cells thus adapted were used as enzyme sources.

Enzyme assay and electronmicroscopical observation. Catalase activity was assayed by the modified method of Patti and Bonet-Maury. ${ }^{5 ;}$ Details have been described in the previous paper. ${ }^{11}$

\section{RESULTS}

1. Induction of the catalase activity by hydrocarbons

The partially induced cells were further cultivated for $4 \mathrm{hr}$ on the media containing various carbon sources. As shown in Fig. 1, the catalase activity was induced strongly by hydrocarbons (A) but not by other carbon sources. When there was no carbon source (G), the activity increased slightly. This fact may be due to the intracellular hydrocarbons incorporated during the first adaptation. In 


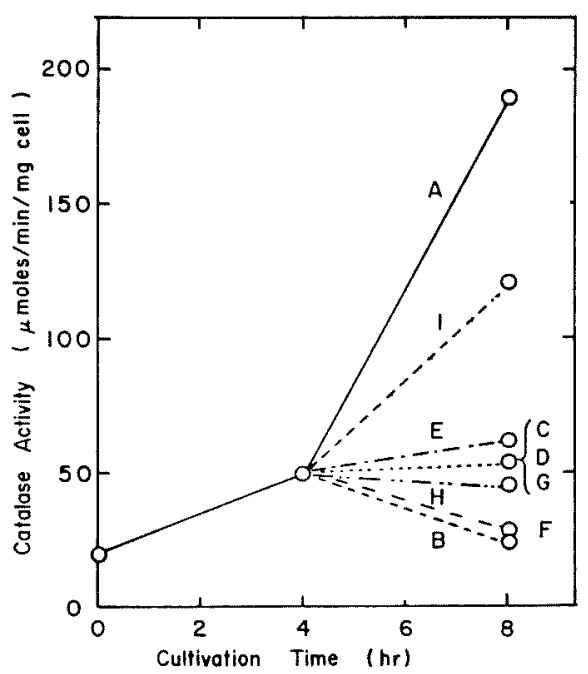

Fig. 1. Effects of Carbon Sources on the Induction of the Catalase Activity.

The partially induced cells cultivated on a hydrocarbon medium for $4 \mathrm{hr}$ were transferred to various media containing the following carbon sources and cultivated for further $4 \mathrm{hr}$ : A, hydrocarbons $(1.0 \mathrm{v} / \mathrm{v}$ $\%) ; \mathrm{B}$, glucose $(1.65 \mathrm{w} / \mathrm{v} \%) ; \mathrm{C}$, galactose $(1.65 \mathrm{w} / \mathrm{v}$ $\%) ; \mathrm{D}, \mathrm{Na}$-acetate $(1.35 \mathrm{w} / \mathrm{v} \%) ; \mathrm{E}$, ethanol $(1.0 \mathrm{v} / \mathrm{v}$ $\%)$; , lauryl alcohol $(1.0 \mathrm{v} / \mathrm{v} \%) ; \mathrm{G}$, none; $\mathrm{H}$, hydrocarbons $(1.0 \mathrm{v} / \mathrm{v} \%)+$ glucose $(5.0 \mathrm{w} / \mathrm{v} \%)$; and $\mathrm{I}$, hydrocarbons $(1.0 \mathrm{v} / \mathrm{v} \%)+$ galactose $(5.0 \mathrm{w} / \mathrm{v} \%)$.

the case of galactose (C), acetate (D) or ethanol (E) as the sole carbon source, the activity was maintained at the same level of that of the partially induced cells, but as to glucose (B) and lauryl alcohol $(\mathrm{F})$ the activity was reduced significantly. In the presence of hydrocarbons, supplementary galactose (I) did not show an inhibitory effect on the induction of the activity. On the other hand, supplementary glucose $(\mathbf{H})$ completely repressed the induction of the activity by hydrocarbons.

2. Effect of glucose concentration on the induction of the catalase activity

The partially induced cells were transferred to the hydrocarbon media containing various concentrations of glucose, and cultivated for $4 \mathrm{hr}$. As shown in Table I, the catalase activity was much repressed even at the concentration of $0.5 \%$ or $0.2 \%$ of glucose. These facts suggest that the induction of the catalase activity in $C$. tropicalis may be very sensitive to glucose.
Table I. Effect of Glucose Concentration on the Catalase Induction IN Candida tropicalis pK 233

The partially induced cells cultivated for $4 \mathrm{hr}$ on a hydrocarbon medium were transferred to the media shown in the Table and cultivated for further $4 \mathrm{hr}$.

\begin{tabular}{lcc}
\hline \multicolumn{1}{c}{ Condition } & $\begin{array}{c}\text { Relative } \\
\text { activity(\%) }\end{array}$ & $\begin{array}{c}\text { No. of } \\
\text { experiments }\end{array}$ \\
\hline No carbon source & 100 & 7 \\
Hydrocarbon $(1 \%)$ & $263 \pm 53$ & 7 \\
-+ Glucose $(5 \%)$ & $65 \pm 18$ & 6 \\
$-+-\quad(1 \%)$ & 61 & 1 \\
$-+-\quad(0.5 \%)$ & 53 & 1 \\
$-+-\quad(0.2 \%)$ & 50 & 1 \\
\hline
\end{tabular}

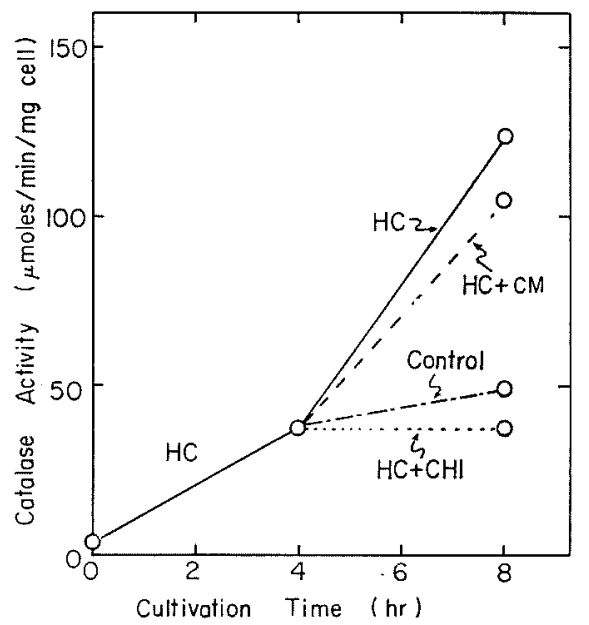

FIG. 2. Effects of Antibiotics on the Induction of the Catalase Activity.

The partially induced cells cultivated on a hydrocarbon medium for $4 \mathrm{hr}$ were transferred to the media containing the following compounds and cultivated for further $4 \mathrm{hr}$ : $\mathrm{HC}$, hydrocarbons $(1.0 \mathrm{v} / \mathrm{v} \%$; $\mathrm{HC}+\mathrm{CM}$, hydrocarbons + chloramphenicol (1 mg/ $\mathrm{ml}) ; \mathrm{HC}+\mathrm{CHI}$, hydrocarbons + cycloheximide $(1 \mu \mathrm{g} / \mathrm{ml})$; and Control, no substrate.

\section{Effects of antibiotics on the induction of the catalase activity}

The partially induced cells were transferred to the hydrocarbon medium containing cycloheximide $(1 \mu \mathrm{g} / \mathrm{ml})$ or chloramphenicol $(1 \mathrm{mg} /$ $\mathrm{ml}$ ), and cultivated for $4 \mathrm{hr}$. As shown in Fig. 2, cycloheximide, which is well known as an inhibitor of cytoplasmic protein synthesis, repressed the induction of the catalase activity by hydrocarbons completely. Cyclo- 


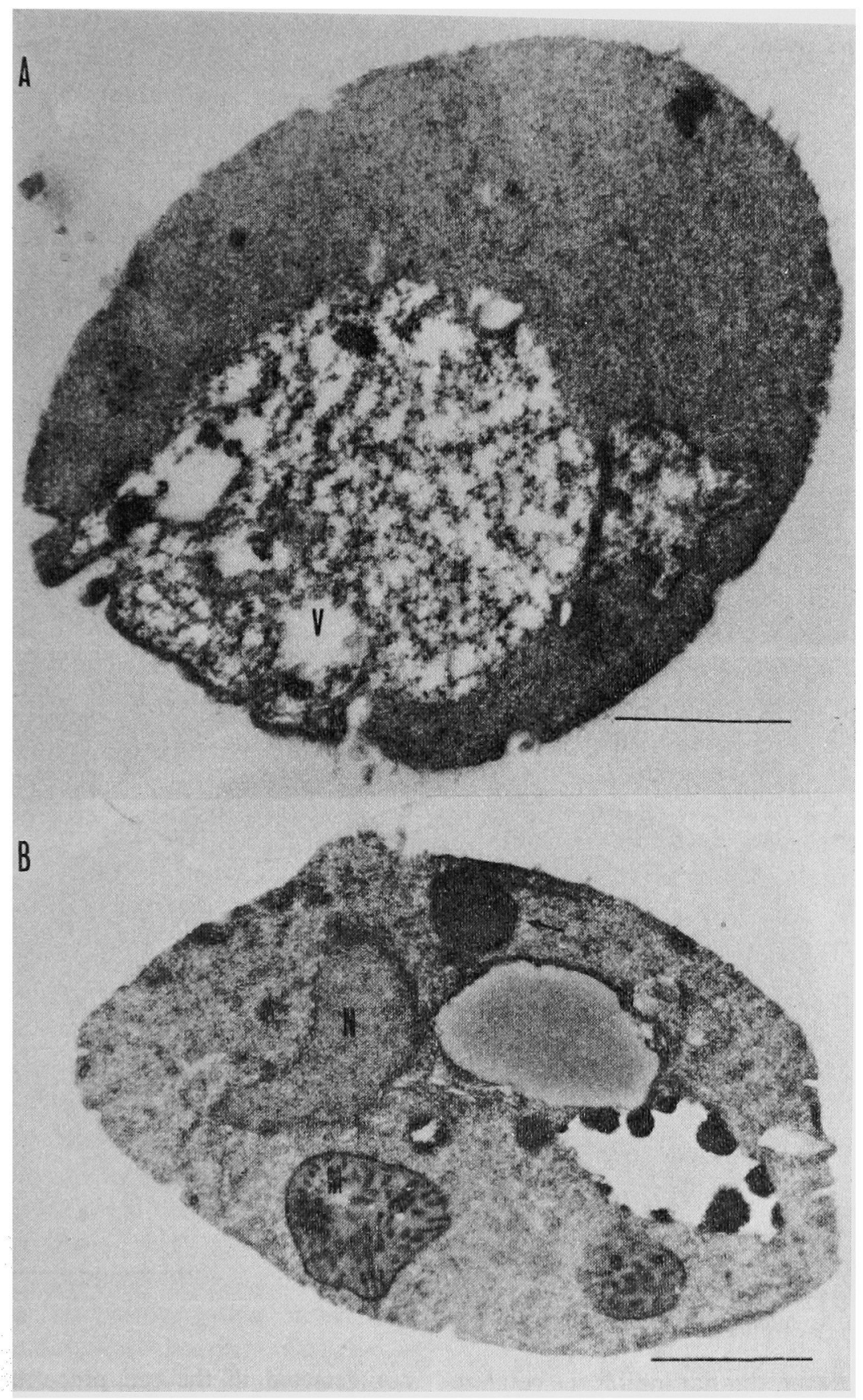

FIG. 3. Fine Structures of Candida tropicalis pK 233.

The precultured cell (A) on malt extract for $22 \mathrm{hr}$ was transferred to a hydrocarbon medium and cultured for $1 \mathrm{hr}$ (B), $4 \mathrm{hr}$ (C) or $8 \mathrm{hr}$ (D). The cells were fixed with glutaraldehyde and then the cell wall was digested by use of Arthrobacter luteus lytic enzyme (K. Kitamura et al., Arch. Biochem. Biophys., 145, 402 (1971)). To detect the localization of catalase activity, the cell thus treated was subjected to the DAB (3,3'-diaminobenzidine) reaction as reported in our previous paper. ${ }^{11} \quad \mathrm{~N}$ : nucleus, $\mathrm{M}$ : mitochondria, V: vacuole, Arrows $(\leftarrow)$ : microbodies. 

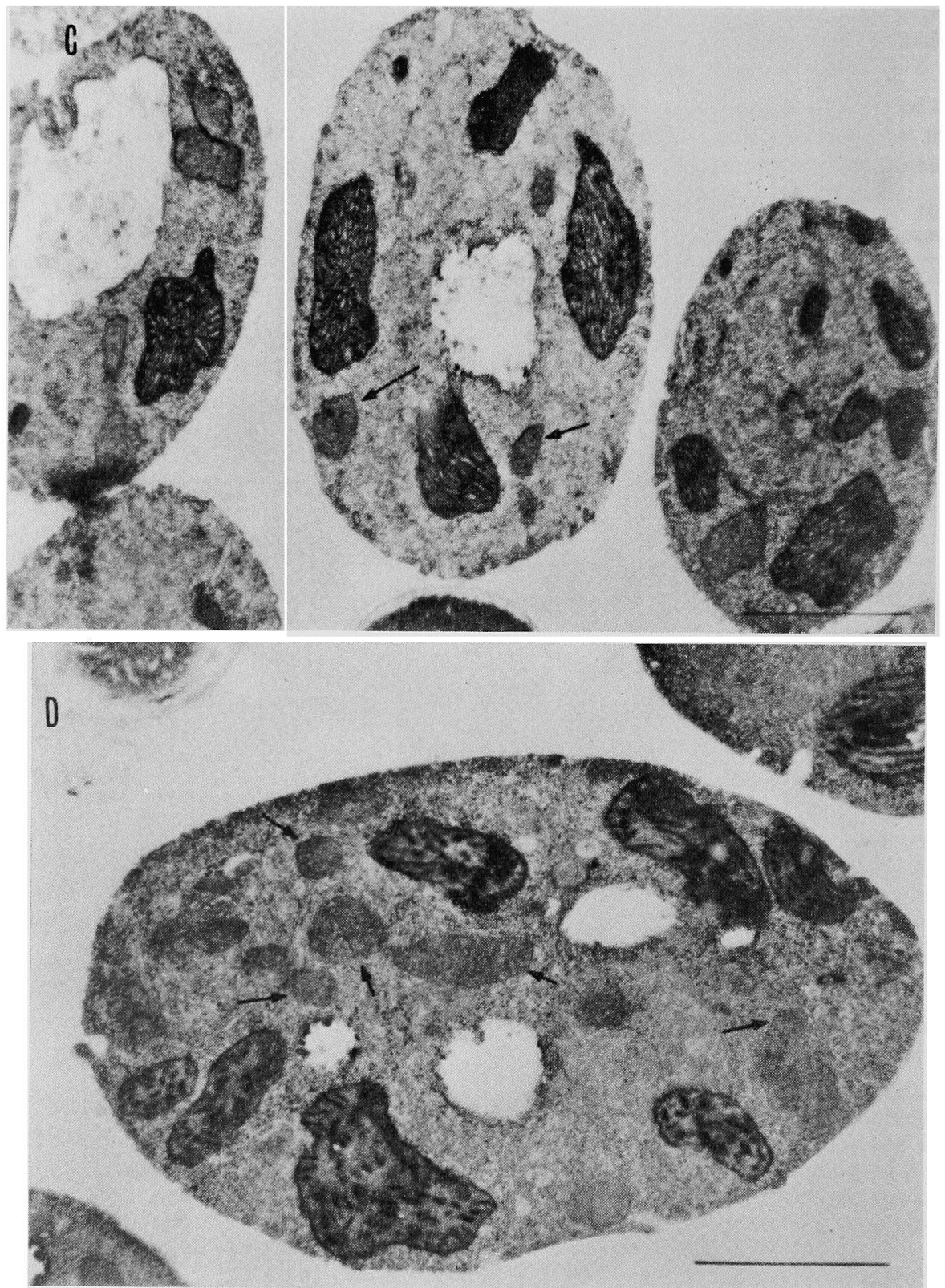

FIG. 3. (continued) C and D.

heximide, however, did not inhibit the catalase activity in vitro. On the other hand, chloramphenicol did not show any effect on the induction of the catalase activity. These results suggested that catalase induced by hydrocarbons seemed to be cytoplasmic protein.

\section{Electronmicroscopical observation}

As shown in Fig. 3-A, any microbody was not detected in the cell precultured on malt extract for $22 \mathrm{hr}$. Only one microbody was observed clearly in the cell cultured with hydrocarbons for $1 \mathrm{hr}$ (Fig. 3-B). In the partially induced cell cultured with hydrocarbons for $4 \mathrm{hr}$ (Fig. 3-C), the number of microbodies was about $4 \sim 5$ per cell section, while that of microbodies increased upto about $8 \sim 10$ per cell section in the cell adapted to hydrocarbons 
for further $4 \mathrm{hr}$ (Fig. 3-D). The catalase activities were $12,18,59$ and $198 \mu$ moles $/ \mathrm{min} / \mathrm{mg}$ cells in the precultured cell, the one hourcultured cell, the partially induced cell and the adapted cell, respectively.

Thus, the increase of the catalase activity occurred in harmony with the increase of microbodies. The detailed studies on the relationship between the catalase activity and the occurrence of microbodies will be published elsewhere.

\section{DISCUSSION}

The catalase activity of $C$. tropicalis $\mathrm{pK} 233$ was strongly induced only by hydrocarbons but not by glucose, galactose, ethanol, acetate or lauryl alcohol. Furthermore, characteristic microbodies $^{1)}$ appeared in the cells during the incubation with hydrocarbons, being in accord with the increase of the catalase activity. These results strongly suggested that the catalase activity and the concomitant increase of microbodies might be essential for the metabolism of hydrocarbons. The difference in the inducibility of catalase between hydrocarbons and lauryl alcohol may indicate that catalase will play an important role in the initial oxidation of hydrocarbons rather than in the $\beta$-oxidation of fatty acids.

As shown in Fig. 1 and Table $I$, in the presence of hydrocarbons, supplementary glucose even at the lowest concentration tested repressed completely the induction of the catalase activity, whereas supplementary galactose did not show significant effect. In the absence of hydrocarbons, galactose was not effective for the induction but glucose rather reduced the activity. Besides, as we described in a previous paper, ${ }^{1}$ the catalase activity of glucose-grown cells of $C$. tropicalis did not show significant changes throughout the cultivation period, although those of the cells grown on other substrates had the maximal activities at the exponential growth phase. These facts suggested the possibility of "glucose repression." Although it has not yet been clear whether these phenomena were due to "catabolite repression" or inhibition of the incorporation of hydrocarbons by glucose, the former is more probable because the morphological change of this yeast depending upon hydrocarbons was observed when grown on a hydrocarbon medium supplemented with glucose. ${ }^{4 \prime}$ Cyclic AMP, which was applied toward protoplasts of Saccharomyces cerevisiae $e^{6)}$ to eliminate the glucose effect, was not effective on the derepression of the catalase induction in the intact cells of $C$. tropicalis. However, it is the problem whether cyclic AMP was incorporated into the intact yeast cells or not. Details are now under investigation.

The catalase activity induced by hydrocarbons should be resulted from cytoplasmic protein synthesis as shown in Fig. 2. We have already clarified cytochemically that the catalase activity of hydrocarbon-grown C. tropicalis was localized in microbodies. These observations coincide with the fact that microbody ("peroxisome") has been known as the cytoplasmic granules.

\section{REFERENCES}

1) Y. Teranishi, A. Tanaka, M. Osumi and S. Fukui, Agr. Biol. Chem., 38, 1213 (1974).

2) H.-P. Hoffmann, A. Szabo and C. J. Avers, $J$. Bacteriol., 104, 581 (1970).

3) C. J. Avers, Sub-cell. Biochem., 1, 25 (1971).

4) M. Hirai, S. Shimizu, Y.Teranishi, A. Tanaka and S. Fukui, Agr. Biol. Chem., 36, 2335 (1972).

5) F. Patti and P. Bonet-Maury, Bull. Soc. Chem. Biol., 35, 1177 (1953).

6) M. Fang and R. A. Butow, Biochem. Biophys. Res. Commun., 41, 1579 (1970). 